\title{
IDENTIFIKASI TUMBUHAN TINGKAT TINGGI (PHANEROGAMAE) DI KAMPUS II UINSU
}

\author{
Adi Hartono 1*, Miza Nina Adlini 1, Yusran Efendi Ritonga 2, Muhammad Iqbal H. Tambunan ${ }^{1}$, \\ Martua Syahriadi Nasution 1, Jumiah 1 \\ 1 Universitas Islam Negeri Sumatera Utara \\ 2 Biologi Pecinta Alam Sumatera Utara \\ *adihartono852@yahoo.com
}

\begin{abstract}
ABSTRAK
Tumbuhan tingkat tinggi (Phanerogamae) merupakan tumbuhan berbiji yang berkembang biak secara seksual. Tumbuhan ini memiliki persebaran yang cukup luas dan lazim ditemukan di berbagai daerah. Kampus II UINSU merupakan kampus yang memiliki keanekaragaman tumbuhan tingkat tinggi yang cukup bervariasi. Oleh karena itu, penelitian ini bertujuan untuk mengidentifikasi tumbuhan tingkat tinggi (Phanerogamae) yang terdapat di Kampus II UINSU Metodologi penelitian yang digunakan ialah metode survey eksploratif dan deskriptif, dengan melakukan pendataan tumbuhan serta mengamati morfologi dan deskripsi tumbuhan tersebut. sampel dikoleksi dalam bentuk segar dan diidentifikasi di laboratorium Tadris Biologi FITK UINSU. Identifikasi tumbuhan menggunakan prosedur pendataan ciri morfologi tumbuhan dan kunci identifikasi yang bersumber dari buku Tjitrosoepomo (2010). Hasil penelitian menunjukkan bahwa terdapat dua sub divisi tumbuhan, yaitu sub divisi Angiospermae dan Gymnospermae. Pada sub divisi Angiospermae ditemukan 6 ordo dengan 9 famili pada kelas Monocotyledonae dan 25 ordo dengan 32 famili pada kelas Dicotyledonae. Sedangkan, pada sub divisi Gymnospermae ditemukan 1 kelas dengan 2 ordo tumbuhan tingkat tinggi (Phanerogamae) yang ditemukan di Kampus II UINSU.
\end{abstract}

Kata Kunci: Identifikasi, Kampus II UINSU, Tumbuhan Tingkat Tinggi (Phanerogamae),

\begin{abstract}
Higher plants (Phanerogamae) are seed plants that breed sexually. This plant has a fairly wide distribution and is commonly found in various regions. Campus II UINSU is a campus that has a high diversity of plants which is quite varied. Therefore, this study aims to identify higher plants (Phanerogamae) found on campus II of UINSU. The research methodology used in this research is to use exploratory and descriptive survey methods, by collecting plant data and observing the morphology and description of the plant. The results showed that there was 1 class with 2 different orders in the Gymnosperms sub-division. Meanwhile, in the Angiosperms subdivision, 6 orders with 9 families were found in the Monocotyledonae class and 25 orders with 32 families in the higher plant Dicotyledonae class (Phanerogamae) found on UINSU Campus II.
\end{abstract}

Keywords: Identification, Higher Plants (Phanerogamae), Campus II UINSU

\section{PENDAHULUAN}

Tumbuhan tingkat tinggi (Phanerogamae) merupakan golongan tumbuhan yang memiliki biji dan berkembang biak secara seksual. Tumbuhan ini juga dikenal sebagai tumbuhan Spermatophyta (dalam bahasa Yunani, Sperma = biji dan Phyta=phyton= tumbuhan) dan Embryophyta Siphonogama (dalam bahasa Yunani, Embryon= embrio= lembaga, Phyton= tumbuhan, Siphon= pipa, buluh, Gamein = kawin). Biji pada tumbuhan ini berasal dari bakal biji yang analog dengan makrosporangium. Di dalamnya, dihasilkan makrospora yang akan berkembang menjadi makroprotalium dengan arkegonium serta sel telurnya (Tjitrosoepomo, 2010).

Tumbuhan Phanerogamae tergolong tumbuhan dengan tingkat perkembangan filogenetik tertinggi karena memiliki biji. Secara ontogeny, biji pada tumbuhan ini menjadi alat reproduksi generatif, karena proses terjadinya didahului oleh peristiwa seksual. Embrio tumbuhan biji bersifat bipolar atau dwipolar, tidak hanya kutub batang yang tumbuh dan 
berkembang membentuk batang, cabang, dan daun. Tetapi, kutub akarnya pun tumbuh dan berkembang membentuk sistem perakarannya (Ulfa, 2019).

Divisi tumbuhan biji (Phanerogamae) secara klasik dapat dibedakan dalam dua sub divisi, yaitu tumbuhan biji terbuka (Gymnospermae) dan tumbuhan biji tertutup (Angiospermae). Tumbuhan berbiji terbuka (Gymnospermae) merupakan sub divisi tumbuhan biji yang memiliki bakal biji dengan 1 integumen terbuka, sehingga buah tidak dilindungi oleh daun buah. Sedangkan, tumbuhan berbiji tertutup (Angiospermae) merupakan kelompok tumbuhan yang bakal bijinya selalu diselubungi oleh bakal buah. Sub divisi tumbuhan biji tersebut digolongkan kembali ke dalam beberapa ordo dan family yang disesuaikan dengan karakteristiknya masing-masing (Sastria, 2018).

Tumbuhan biji yang terdapat di permukaan bumi saat ini terdiri dari 170.000 jenis tumbuhan. Sehingga dapat ditaksir bahwa separuh kekayaan flora dan fauna meliputi 300.000 jenis tumbuhan. (Tjitrosoepomo, 2013). Penyebaran tumbuhan tinggi ini sangat dipengaruhi oleh faktor bioekologi. Faktor bioekologi secara umum terbagi atas dua yakni faktor abiotik dan biotik Faktor abiotik terdiri atas faktor-faktor lingkungan yang bersifat non biologis seperti iklim (suhu udara, kelembaban udara, intensitas cahaya), tanah dan kondisi fisik lingkungan lainnya (Hakim, 2019). Sementara itu, faktor biotik berhubungan dengan keadaan hidup tumbuhan tersebut yang terdiri dari perubahan morfologi, fenologi, fisiologi, maupun molekularnya sebagai respon adaptasi (Wasilah, 2019).

Identifikasi merupakan suatu kegiatan untuk mengenali identitas atau jati diri tumbuhan. Proses identifikasi ini berhubungan dalam menentukan nama tumbuhan yang benar serta penempatannya dalam sistem klasifikasi secara tepat. Klasifikasi merupakan susunan tingkatan taksonomi makhluk hidup yang digunakan untuk mempermudah pengelompokan makhluk hidup. Identifikasi dan klasifikasi ini dilakukan dengan melakukan pengamatan terhadap morfologi atau karakter pada tumbuhan (Suraya, 2019).

Sehubungan dengan hal tersebut, sejumlah penelitian tentang identifikasi tumbuhan tingkat tinggi sudah pernah dilakukan. Beberapa penelitian terkait dengan identifikasi tumbuhan tingkat tinggi seperti Inventarisasi Keanekaragaman Tumbuhan Tingkat Tinggi di Kecamatan Medan Amplas (Ulfa, 2019) dan Identifikasi Apocynaceae sebagai Perangkat Media Pembelajaran (Prabowo, 2019). Peneliti dan tim merasa perlu dilakukan inventarisasi tumbuhan Phanerogamae, untuk mengetahui keanekaragaman Phanerogamae di Kampus II UINSU. Selain itu, penelitian ini bertujuan untuk mengetahui data tumbuhan yang tersebar di lokasi Kampus untuk dipelajari lebih khusus dan sebagai sumber informasi bagi mahasiswa tadris biologi dalam mempelajari tumbuhan Phanerogamae. Terutama dalam klasifikasi, penelitian dan pemanfaatan tumbuhan tersebut.

\section{METODE}

Penelitian dilakukan di kampus II UINSU di jalan Williem Iskandar pasar V Medan Estate pada bulan Januari 2019 sampai Juli 2020. Alat dan bahan yang digunakan yaitu: alat tulis, tabel pengamatan, kamera digital dan buku kunci identifikasi tumbuhan tingkat tinggi. Sampel penelitian yaitu tumbuhan tingkat tinggi yang terdapat di areal lahan Kampus II UINSU.

Pengamatan menggunakan metode eksplorasi (jelajah) secara langsung pada area kampus II UINSU. Setiap tanaman Phanerogamae yang ditemukan dicatat kemudian diambil sampelnya untuk dilakukan herbarium. Identifikasi tumbuhan dilakukan dengan pengamatan karakter morfologi tumbuhan meliputi ciri-ciri khusus pada setiap kelas dan family maupun genus pada klasifikasi tumbuhan Phanerogamae. Meliputi daun, batang, dan bunga serta buah. Data disesuaikan dengan buku referensi Tjitrosoepomo (2010). Data kemudian dikumpulkan untuk dilakukan deskripsi berdasarkan family. 
Adi Hartono et al., Identifikasi Tumbuhan Tingkat Tinggi (Phanerogamae) Di Kampus II UINSU Jurnal Biolokus: Jurnal Penelitian Pendidikan Biologi Dan Biologi Vol.3 (2)

\section{Tahap Persiapan}

Meliputi penyediaan alat dan bahan yang diperlukan, serta penentuan sejumlah titik lokasi pengamatan yang terbagi menjadi 6 titik (A, B, C, D, E, F,) yang tersebar pada masingmasing fakultas di kampus II UINSU.

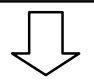

Tahap Eksplorasi

Meliputi pengamatan dan pengumpulan data tumbuhan tingkat tinggi secara langsung

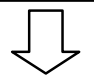

Tahap Pasca Eksplorasi

Meliputi pengidentifikasian tumbuhan tingkat tinggi menggunakan buku kunci determinasi, kepustakaan, validasi dan pembuatan jurnal.

Gambar 1. Alur Kerja Identifikasi Tumbuhan Tingkat Tinggi (Phanerogamae).

\section{HASIL DAN PEMBAHASAN}

Berdasarkan penelitian yang telah dilakukan, maka dapat diketahui bahwa keanekaragaman tumbuhan tingkat tinggi
(Phanerogamae) yang terdapat di Kampus II UINSU dapat dilihat melalui tabel 1.

Kampus II UINSU memiliki areal lahan yang banyak ditumbuhi oleh tumbuhan tingkat tinggi (Phanerogamae). Tumbuhan ini hidup di sepanjang areal lahan kampus tersebut. Spesies tumbuhan tingkat tinggi yang ditemukan sangat bervariasi dan beranekaragam.

Berdasarkan tabel pengamatan di bawah, maka dapat diketahui bahwa tumbuhan tingkat tinggi (Phanerogamae) yang berada di areal Kampus II UINSU terdiri dari dua sub divisi utama, yaitu Gymnospermae dan Angiospermae. Pada sub divisi Gymnospermae, terdapat 1 kelas dengan 2 ordo yang berbeda, yaitu kelas Coniferae serta ordo Cupressales dan Araucariales. Masingmasing ordo tersebut memiliki 1 famili dan 1 spesies yang berbeda. Tumbuhan dari ordo Cupressales yang ditemukan yaitu famili Cupressaceae, sedangkan dari ordo Araucariales yaitu famili Araucariaceae.

Tabel 1. Keanekaragaman Tumbuhan Tingkat Tinggi (Phanerogamae) di Kampus II UINSU

(Sistem Klasifikasi Berdasarkan: Tjitrosoepomo, 2010)

\begin{tabular}{|c|c|c|c|c|c|c|}
\hline No & $\begin{array}{c}\text { Sub } \\
\text { Divisi }\end{array}$ & Kelas & Ordo & Famili & Spesies & Daerah \\
\hline 1 & \multirow{2}{*}{$\begin{array}{l}\text { Gymnos } \\
\text { permae }\end{array}$} & \multirow{2}{*}{ Coniferae } & Cupressales & Cupressaceae & Thuja orientalis L. & Cemara kipas \\
\hline 2 & & & Araucariales & Araucariaceae & Araucaria heterophylla L. & Cemara norlfolk \\
\hline 3 & \multirow{23}{*}{$\begin{array}{l}\text { Angios } \\
\text { permae }\end{array}$} & \multirow{23}{*}{$\begin{array}{l}\text { Dicotyledon } \\
\text { eae }\end{array}$} & \multirow{2}{*}{ Rutales } & \multirow{2}{*}{ Meliaceae } & Swietenia mahagoni (L) Jacq. & Mahoni \\
\hline 4 & & & & & Swietenia macrophylla (L) Jacq. & Mahoni \\
\hline 5 & & & Sapindales & Anacardiaceae & Mangifera indica $\mathrm{L}$. & Mangga \\
\hline 6 & & & \multirow{2}{*}{ Myrtales } & \multirow{2}{*}{ Combretaceae } & Terminalia catappa L. & Ketapang \\
\hline 7 & & & & & Terminalia mantaly L. & Katapang kencana \\
\hline 8 & & & Urticales & Moraceae & Artocarpus integra L. & Nangka \\
\hline 9 & & & Urticales & Moraceae & Ficus benjamina $\mathrm{L}$. & Beringin \\
\hline 10 & & & Casuarinales & Casuarinaceae & Casuarina equisetifolia $\mathrm{L}$. & Cemara Laut \\
\hline 11 & & & \multirow{5}{*}{ Euphorbiales } & \multirow{5}{*}{ Euphorbiaceae } & Hura crepitans L. & Buah roda \\
\hline 12 & & & & & Manihot esculenta L. & Singkong \\
\hline 13 & & & & & Euphorbia milii L. & Mahkota duri \\
\hline 14 & & & & & Euphorbia tirucalli L. & Patah tulang \\
\hline 15 & & & & & Phyllanthus urinaria L. & Meniran \\
\hline 16 & & & \multirow{4}{*}{ Myrtales } & \multirow{4}{*}{ Myrtaceae } & Syzygium oleana L. & Pucuk merah \\
\hline 17 & & & & & Syzygium malaccense L. & Jambu bol \\
\hline 18 & & & & & Syzygium aqueum L. & Jambu air \\
\hline 19 & & & & & Psidium guajava $\mathrm{L}$. & Jambu biji \\
\hline 20 & & & Ebenales & Sapotaceae & Mimusops elengi L. & Tanjung \\
\hline 21 & & & Fabales & Fabaceae & Erythrina variegate L. & Dadap \\
\hline 22 & & & Oleales & Oleaceae & Jasminum grandiflorum L. & Bunga melati \\
\hline 23 & & & \multirow{3}{*}{ Asterales } & \multirow{3}{*}{ Asteraceae } & Gerbera jamesonii L. & Bunga hebras \\
\hline 24 & & & & & Eclipta alba L. & Urang aring \\
\hline 25 & & & & & Elephantopus scaber L. & Tapak liman \\
\hline
\end{tabular}


Adi Hartono et al., Identifikasi Tumbuhan Tingkat Tinggi (Phanerogamae) Di Kampus II UINSU Jurnal Biolokus: Jurnal Penelitian Pendidikan Biologi Dan Biologi Vol.3 (2)

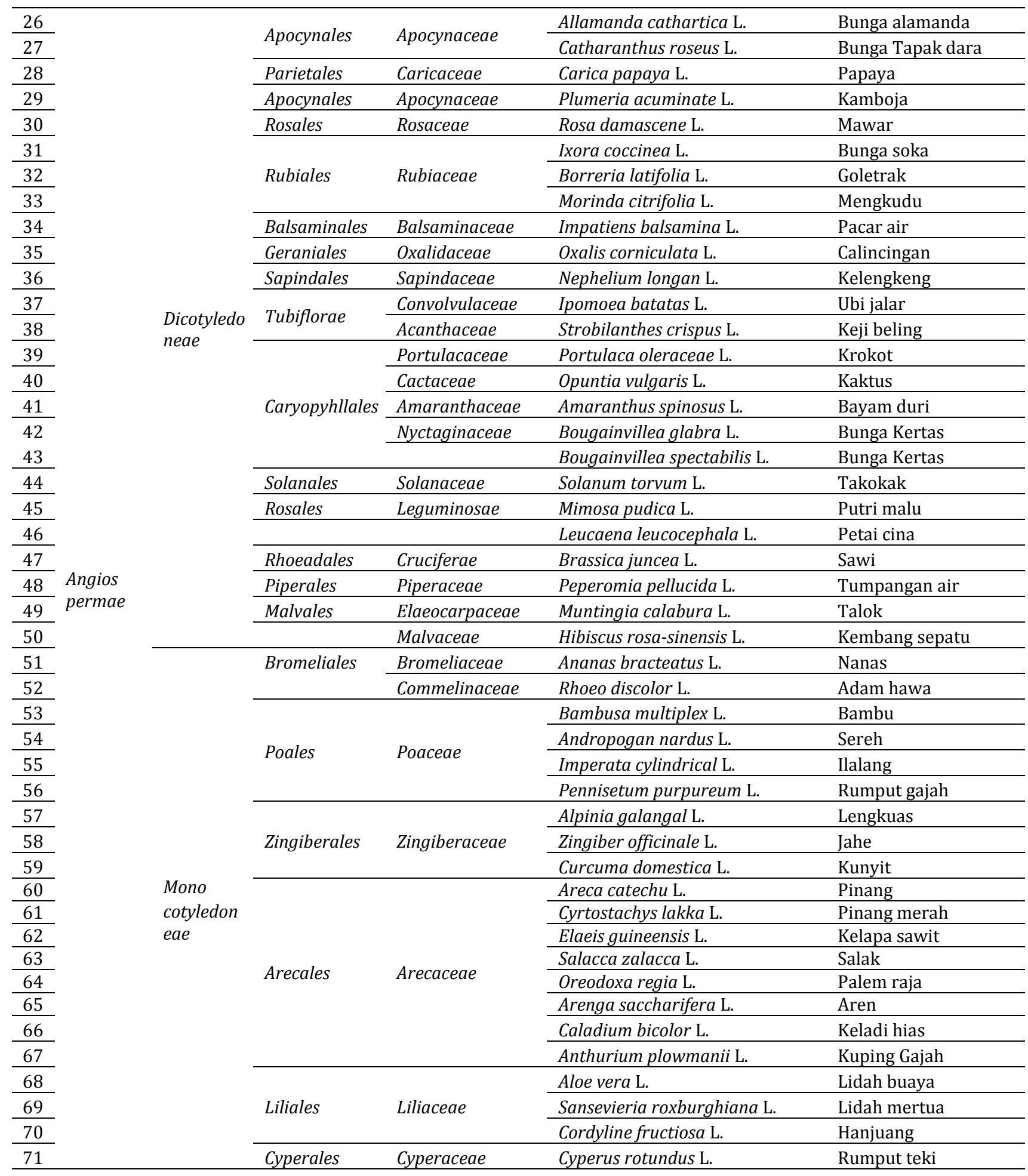

Menurut Tjitrosoepomo (2010) menyatakan bahwa Coniferae merupakan kelas tumbuhan yang memiliki tajuk berbentuk kerucut dan daun berbentuk jarum. Sementara itu, Triawati (2019) menyatakan bahwa tumbuhan Coniferae merupakan tumbuhan yang eksotis dan berpotensi untuk memberikan ketenangan dan kesejukan bagi setiap orang yang berada disekitarnya. Oleh karenanya, tumbuhan ini dapat menyajikan suasana yang indah dan asri, sehingga mahasiswa dapat menghilangkan rasa penat dengan berteduh dibawahnya.

Pada sub divisi Angiospermae, terdapat 2 kelas tumbuhan tingkat tinggi (Phanerogamae) yang ditemukan, yaitu kelas Monocotyledonae 
dan Dicotyledonae. Tumbuhan yang ditemukan dari kelas Monocotyledonae terdiri dari 6 ordo dengan 9 famili. Ordo tumbuhan tersebut yaitu Arecales, Liliales, Cyperales, Zingiberales, Bromeliales, dan Poales. Adapun 9 famili tumbuhan dari ordo tersebut yang ditemukan dilokasi pengamatan, yaitu Arecaceae, Araceae, Liliaceae, Cyperaceae, Zingiberaceae, Bromeliaceae, Commelinaceae, dan Poaceae.

Menurut Silalahi (2019) Araceae merupakan famili tanaman yang banyak dimanfaatkan sebagai tanaman hias karena memiliki daun dan warna batang yang indah. Sehingga, keberadaannya dapat memperindah lingkungan Kampus II UINSU. Sementara itu, Yassir (2019) menyatakan bahwa Zingiberaceae merupakan tumbuhan rimpang-rimpangan yang berpotensi sebagai tanaman obat karena mengandung minyak atsiri dan alkaloid yang dapat meningkatkan daya tahan tubuh. Apabila dibudidayakan secara berkesinambungan, famili Zingiberaceae dapat mengantarkan kampus II UINSU berpotensi terhadap konservasi tanaman herbal yang dapat mendukung kegiatan perkuliahan di bidang Biologi, khususnya pada mata kuliah Botani yang mengintegrasikan pemanfaatan tumbuhan melalui konsep Etnobotani. Hal ini sesuai dengan Mukhoyyaroh (2020) yang menyatakan bahwa suatu tanaman Etnobotani memberikan kekayaan inventarisasi suatu jenis tanaman di areal tertentu yang dapat dimanfaatkan oleh masyarakat. Tanaman herbal dapat digolongkan ke dalam jenis tanaman Etnobotani karena memberikan manfaat bagi masyarakat luas.

Adapun spesies tumbuhan dari kelas Monocotyledoneae yang paling banyak ditemukan dari famili Arecaceae dan Poaceae. Hal ini sesuai dengan penelitian Indrawati (2018) yang menyatakan bahwa famili Poaceae memiliki daya adaptasi yang tinggi, distribusi luas, dan mampu tumbuh pada lahan kering maupun tergenang. Famili Poaceae berkemampuan menyebar dengan cepat karena biji yang ringan dan mudah terbawa angin. Selain itu, sistem perakaran rhizoma dalam tanah dan stolon di permukaan tanah menyebabkan kemampuan ekspansinya tinggi dan dapat mencapai kawasan yang jauh. Hal yang sama juga diungkapkan oleh Destarianti (2017) yang menyatakan bahwa famili Poaceae merupakan famili tumbuhan tingkat tinggi yang dapat tumbuh pada berbagai habitat, terutama habitat yang memiliki intensitas cahaya yang tinggi. Hal ini sesuai dengan hasil penelitian yang diperoleh, famili Poaceae banyak ditemukan di lahan terbuka yang terpapar sinar cahaya matahari langsung.

Menurut Hutasuhut (2018) Arecaceae merupakan tumbuhan yang banyak digunakan dalam berbagai aspek dalam kehidupan manusia. Misalnya, digunakan sebagai bahan bangunan, alat-alat rumah tangga, bahan kerajinan, sumber pangan, minyak, dan energi, tanaman obat, tanaman hias, dan konservasi lingkungan. Sementara itu, Arisandi (2019) mengungkapkan bahwa Poaceae merupakan salah satu famili tumbuhan Angiospermae yang bersifat kosmopolitan yang memiliki pola penyebaran yang cukup luas. Hal ini disebabkan, famili tumbuhan tersebut melakukan penyerbukan dengan perantaraan angin. Oleh karena penyebarannya yang cukup luas, famili Poaceae bermanfaat dari segi ekonomi dan ekologisnya. Dari segi ekonomi, misalnya bambu banyak digunakan sebagai bahan bangunan, perkakas rumah tangga, dan bahan kerajinan. Sedangkan, dari segi ekologis, famili Poaceae bermanfaat untuk membantu mengurangi hempasan air hujan pada permukaan tanah dan dalam hal pengawetan tanah. Berdasarkan pemaparan tersebut dapat dipahami bahwa keberadaan famili Arecaceae dan Poaceae di kampus II UINSU dapat menjadi aset berharga untuk dibudidayakan secara signifikan bagi tercapainya pemanfaatan tumbuhan tersebut dalam aspek ekonomi dan ekologi.

Tumbuhan yang ditemukan dari kelas Dicotyledonae terdiri dari 25 ordo dengan 32 famili. Berdasarkan data pengamatan tersebut, maka dapat diketahui bahwa spesies tumbuhan paling banyak ditemukan dari famili Euphorbiaceae dengan 5 spesies. Sedangkan, 
pada famili Myrtaceae ditemukan 4 spesies, famili Asteraceae dan Rubiaceae ditemukan 3 spesies, famili Apocynaceae dan Leguminosae (Fabaceae) ditemukan 2 spesies, serta famili lainnya yang hanya ditemukan 1 spesies.

Menurut Prabowo (2019) Euphorbiaceae merupakan keluarga besar tanaman berbunga yang memiliki spesies terbanyak, yaitu sekitar 2000 spesies tanaman. Tumbuhan ini tersebar di daerah tropis, mulai dataran rendah hingga dataran tinggi. Pesatnya persebaran tumbuhan ini disebabkan karena biji berukuran kecil seperti pasir dan berwarna cokelat yang mudah tumbuh dan berkembang di tempat yang sesuai. Salah satu karakteristik famili Euphorbiaceae ialah kemampuannya untuk mengeluarkan getah berwarna putih bila tubuhnya dilukai.

Nopiyanti (2019) mengungkapkan bahwa famili Euphorbiaceae banyak dimanfaatkan sebagai tanaman obat karena mengandung metabolit sekunder berupa minyak atsiri, alkaloid, dan tanin yang tersimpan dalam vakuola daun tumbuhan tersebut. Selain itu, minyak nabati yang terkandung dalam tumbuhan ini dapat diolah menjadi bahan bakar pengganti minyak bumi dan bahan bakar fosil. Sementara itu, menurut Nurasyikin (2019) menyatakan bahwa famili Myrtaceae banyak dimanfaatkan sebagai tanaman hias dan tanaman peneduh. Buah yang dihasilkan memiliki kandungan gizi yang cukup penting bagi kesehatan. Khususnya, pada tanaman pucuk merah (Syzygium oleana L.) yang memiliki kandungan antosianin yang berperan dalam menangkal radikal bebas dalam tubuh.

Tjitrosoepomo (2010) menegaskan bahwa Asteraceae merupakan famili tumbuhan yang memiliki daun tunggal tersebar atau berhadapan dan bunga dalam bongkol kecil dengan daun pembalut. Famili ini juga memiliki dua macam bunga yaitu bunga cakram berbentuk tabung dan bunga tepi berbentuk pita. Tumbuhan ini termasuk ke dalam gulma berdaun lebar dan hidup secara terrestrial. Menurut Simanjuntak (2017) famili Asteraceae berkhasiat sebagai tanaman obat karena tumbuhan tersebut memiliki komponen senyawa bioaktif, seperti seskuiterpen, lakton, triterpen pentasiklik, alkohol, alkaloid, tanin, polifenol, saponin, dan sterol yang dapat digunakan untuk bahan pengobatan. Hal serupa juga ditegaskan oleh Sari (2019) yang menyatakan bahwa sejumlah spesies dari famili Asteraceae banyak diberdayakan oleh masyarakat sebagai obat tradisional dengan olahan sebagai ramuan obat.

Menurut Haris (2019) Rubiaceae tergolong ke dalam famili tumbuhan yang hidup secara kosmopolitan dan telah banyak didayagunakan oleh masyarakat sebagai tanaman obat. Riset tentang tumbuhan ini telah membuktikan bahwa Rubiaceae teruji secara klinis memberikan efek farmakologis yang melalui analisis fitokimia yang dikandungnya. Hal yang sama juga ditegaskan oleh Almukarromah (2019) yang menyatakan bahwa famili Rubiaceae memiliki bunga yang indah dan berkhasiat sebagai tanaman obat, khususnya penawar racun dalam tubuh.

Secara keseluruhan, terdapat keanekaragaman tumbuhan Phanerogamae di areal Kampus II UINSU. Adanya keanekaragaman ini disebabkan faktor kemampuan tumbuhan untuk tumbuh dan berkembang dengan baik yang didukung dengan faktor abiotik lingkungan dan faktor biotik seperti polinasi dan hewan pemakan buah (biji). Hal ini sejalan dengan Nurlia (2020) yang menyatakan bahwa penyebaran suatu famili tumbuhan sangat dipengaruhi oleh jumlah benih, kemampuan penyebaran, dan toleransi berbagai ekologi. Sementara itu, menurut Zulharman (2017) menyatakan bahwa suatu pola penyebaran tumbuhan akan mengakibatkan keanekaragaman tumbuhan yang hidup pada suatu lahan tertentu. Penyebaran ini akan dipengaruhi oleh mekanisme lingkungan yang mendorong munculnya jenis tanaman yang berkedudukan sebagai tumbuhan yang mendominasi dan tumbuhan minoritas pada suatu areal lahan tertentu. Tumbuhan yang dominan merupakan tumbuhan yang dapat melakukan efisiensi energi dalam lingkungannya, sehingga dapat 
menggunakan energi secara maksimal sesuai dengan kebutuhannya. Adanya keanekaragaman ini menjadikan lahan sekitaran kampus II UINSU menjadi lokasi yang baik dalam mempelajari klasifikasi tumbuhan secara contekstual yang memiliki potensi untuk diteliti oleh mahasiswa maupun dosen Tadris Biologi.

\section{PENUTUP}

Berdasarkan penelitian yang telah dilakukan, maka dapat disimpulkan bahwa tumbuhan tingkat tinggi (Phanerogamae) yang ditemukan di Kampus II UINSU terdiri dari 2 sub divisi tumbuhan, yaitu Gymnospermae dan Angiospermae. Pada sub divisi Gymnospermae ditemukan 1 kelas dengan 2 ordo yang berbeda. Sedangkan, pada sub divisi Angiospermae, ditemukan adanya 2 kelas tumbuhan, yaitu kelas Monocotyledoneae dan Dicotyledoneae. Pada kelas Monocotyledonae ditemukan 6 ordo dengan 9 famili dan pada kelas Dicotyledoneae ditemukan 25 ordo dengan 32 famili.

Berdasarkan data yang ditemukan, maka dapat diketahui bahwa sejumlah famili tumbuhan Phanerogamae yang ditemukan di kampus II UINSU berpotensi terhadap pemanfaatannya dalam berbagai aspek, seperti aspek ekonomi, ekologi, dan kesehatan. Hal inilah yang dapat mendorong budidaya tumbuhan tersebut dengan lebih mumpuni agar tercipta kawasan Etnobotani dan konservasi tumbuhan tingkat tinggi secara signifikan terutama tumbuhan-tumbuhan potensi lokal daerah Sumatera Utara seperti Andaliman (Zanthoxylum acanthopodium). Budidaya tumbuhan Phanerogamae juga berimplikasi terhadap pengembangan kawasan lingkungan yang asri dan hasil yang diperoleh dari tumbuhan tersebut dapat dimanfaatkan untuk mendukung proses pembelajaran Botani dan meningkatkan taraf kehidupan.

Penelitian ini dimaksudkan untuk mengidentifikasi keanekaragaman tumbuhan tingkat tinggi (Phanerogamae) yang terdapat di Kampus II UINSU. Oleh karena itu, direkomendasikan kepada peneliti lain untuk mengkaji lebih jauh tentang faktor ekologi lokasi pengamatan yang mempengaruhi keberadaan tumbuhan tersebut dan pemberdayaan tumbuhan yang ditemukan. Hal ini dimaksudkan agar mengetahui tindak lanjut pemanfaatan tumbuhan tingkat tinggi di Kampus II UINSU sebagai potensi lokal tumbuhan yang dapat dimanfaatkan yang didukung dengan faktor ekologi di dalamnya.

\section{REFERENSI}

Almukarramah, Ibrahim, \& Sufriadi. (2019). Tanaman Berkhasiat Obat dari Sub Kelas Sympetalae yang Digunakan Masyarakat. Jurnal Sains dan Aplikasi, 7(1), 18-25.

Arisandi, R., Mochamad A. S., \& Dharmono. (2019). Keanekaragaman Familia Poaceae Di Kawasan Rawadesa Sungai Lumbah, Kabupaten Barito Kuala. Jurnal Enviro Scienteae, 15(3), 390-396.

Destarianti, N., Sulistyani \& Yani, E. (2017). Struktur dan Vegetasi Tumbuhan Bawah pada Tegakan Pinus di RPH Kalirajut dan RPH Baturraden Banyumas. Jurnal Scripta Biologica, 4(3), 155-160.

Hakim, M. Furqon. (2019). Kajian Persebaran Jenis Tumbuhan Pada Penambangan Bahangalian C di pagerejo dan Candi mulyo kertek wonosobo. Jurnal Penelitian dan Pengabdian Kepada Masyarakat (JPPKM), 6(2), 84-87.

Haris N.A. \& Anifah T. (2019). Kajian Etnobotani Famili Rubiaceae Oleh Masyarakat Kotatarakan dan Potensinya sebagai Sumber Belajar Biologi. Biopedagogia, 1(1), 75-80.

Hutasuhut, M. A. \& Rasyidah. (2018). Inventarisasi Jenis-Jenis Arecaceae di Kawasan Hutan Taman Nasional Gunung Leuser Desa Telagah Kabupaten Langkat Sumatera Utara. Klorofil: Jurnal Ilmu Biologi dan Terapan, 2(2), 1-7.

Indrawati, Ambardini, S., \& Nyiliantri, H. (2018). Identifikasi Jenis Tumbuhan di Lokasi Pertambangan Nikel PT. Cimmi (Cahaya Modern Metal Indonesia) Kabupaten Konawe Sulawesi Tenggara. BioWallacea: Jurnal Penelitian Biologi, 5(2), 857. 
Mukhoyyaroh, N. I. \& Luchman H. (2020). Etnobotani Pemanfaatan Pisang Lokal (Musa sp.) di Desa Srigonco, Kecamatan Bantur, Kabupaten Malang. Journal of Tropical Biology, 8(1), 43-53.

Nopiyanti, N. \& Linna Fitriyani. (2019). Inventarisasi Jenis-jenis Tumbuhan Famili Euphorbiaceae di Kecamatan Topos Kabupaten Lebongprovinsi Bengkulu. Jurnal Biosilampari, 1(2), 65-72.

Nurasyikin, Siti M., Umi S., \& Heryani. (2019). Teknologi Tepat Guna Sirup Buah Pucuk Merah Mudah dan Aman. Aktualita: Jurnal Penelitian Sosial dan Keagamaan, 9(1), 32-48.

Nurlia \& Karim, W. (2020). Analisis Vegetasi Tumbuhan Angiospermae di Desa Rangaranga Kecamatan Masama Kabupaten Banggai. Edubiotik: Jurnal Pendidikan, Biologi, dan Terapan, 5(1), 71-80.

Prabowo, P. (2019). Pengembangan Perangkat Pembelajaran Berbasis Data Euphorbiaceae Hutan Taman Eden 100. Jurnal Biology Education, Science \& Technology, 2(2), 24-31.

Sastria, E. \& Novi N. (2018). Buku Ajar Botani Phanerogamae. Padang: IAIN Kerinci Press.

Silalahi, M. \& Hotmaulina S. (2019). Keanekaragaman Tumbuhan yang Diperjualbelikan di Nurseri Kranggan, Bekasi, Jawa Barat. Sainmatika: Jurnal Ilmiah Matematika dan Ilmu Pengetahuan Alam, 16(2), 98-109.

Simanjuntak, H. A. (2017). Potensi Famili Asteraceae sebagai Obat Tradisional di Masyarakat Etnis Simalungun Kabupaten Simalungun Provinsi Sumatera Utara. Biolink: Jurnal Biologi Lingkungan, Industri, Kesehatan, 4(1), 11-18.

Suraya, U. (2019). Inventarisasi dan Identifikasi Tumbuhan Air di Danau Hanjalutung Palangka Raya. Jurnal Ilmiah Pertanian dan Kehutanan, 6(2), 149-159.

Tjitrosoepomo, Gembong. (2010). Taksonomi Tumbuhan (Spermatophyta). Yogyakarta: Gadjah Mada University Press.
Tjitrosoepomo, Gembong. (2013). Taksonomi Tumbuhan (Spermatophyta). Yogyakarta: Gadjah Mada University Press.

Triawati, K. (2019). Dataran Toili Wisata Alam: Seribu Cemara di Pantai Minahaki. Jurnal Pariwisata Parama, 1(1), 21-30.

Ulfa, Syarifah Widya. (2019). Inventarisasi Keanekaragaman Tumbuhan Tingkat Tinggi di Kecamatan Medan Amplas Kota Medan Propinsi Sumatera Utara. Jurnal Biology Education Science and Technology, 2(1), 1520.

Wasilah, U., Dian A.G, \& Mukhamad S. (2019). Peran Chaperone pada Tumbuhan: Mini Review. Jurnal Biologi Papua, 11(2), 110-115.

Yassir, M. \& Meliyana. (2019). Jenis Tanaman Obat di Kecamatan Semadam Kabupaten Aceh Tenggara, Jurnal Sains dan Aplikasi, 7(1), 612.

Zulharman. (2017). Analisis Tumbuhan Asing Invasif (Invasive Species) pada Kawasan Revitalisasi Hutan, Blok Argowulan, Taman Nasional Bromo Tengger Semeru, Jurnal Natural, 4(1), 78-87. 